\title{
Reactivity Investigation on Iron-Titanium Oxides for a Moving Bed Chemical Looping Combustion Implementation
}

\author{
Diana C. Campos, Jamal Belkouch, Mourad Hazi, Aïssa Ould-Dris ${ }^{*}$ \\ Laboratoire de Transformation Intégrée de la Matière Renouvelable, Université de Technologie de Compiègne, \\ Compiègne Cedex, France \\ Email: "oulddris@utc.fr
}

Received September 15, 2012; revised October 17, 2012; accepted October 26, 2012

\begin{abstract}
Ilmenite-type natural ore which is constituted mainly of iron-titanium oxide is an interesting candidate as an oxygen carrier in chemical looping combustion (CLC) process. Its reactivity was investigated using methane as reducing gas and air as oxidizing gas. Experiments were carried out in a coupled thermogravimetric-thermo differential analyzer (TGA-DTA). When temperature increases from $700^{\circ} \mathrm{C}$ to $1000^{\circ} \mathrm{C}$, the reaction rate increases by 50 times while the oxygen transfer capacity passes from $1.8 \%$ to $12 \%$. TG-DT analyses showed that the overall mass loss due to ilmenite reduction reached at most $12 \%$. It corresponds to $87 \%$ of theoretical mass loss due to the transformation of $\mathrm{Fe}_{2} \mathrm{TiO}_{5}$ into $\mathrm{Fe}$ and $\mathrm{TiO}_{2}$. It is established that the reduction for the iron-titanium oxides occurs in two steps: $\mathrm{Fe}_{2} \mathrm{TiO}_{5} \rightarrow \mathrm{FeTiO}_{3} \rightarrow$ $\mathrm{Fe}+\mathrm{TiO}_{2}$. The titanium reduction from the state $\mathrm{TiO}_{2}$ to the stage $\mathrm{Ti}_{3} \mathrm{O}_{5}$ was observed as well. This behavior is supported by XRD analysis. Subsequent oxidation of the reduced mineral led to recover the starting oxide. The stability of iron-titanium oxides was established over 35 looping cycles of oxidation-reduction, with an increase of 5\% of oxygen transfer capacity and reactivity in the first 5 cycles and after that, ilmenite reactivity remained constant. At high temperatures, catalytic effect of ilmenite on methane decomposition leading to carbon deposition is observed. The deposited carbon participates in the reactivity of the oxide.
\end{abstract}

Keywords: Ilmenite; Iron-Titanium Oxides; Chemical Looping Combustion; CLC; Methane; Reactivity

\section{Introduction}

In recent years, the increase of greenhouse gases (GHG) emissions is considered as a major environmental problem. The use of fossil fuels for energy production is one of its main causes [1]. Since environmentally friendly sources of energy, such as solar, wind, hydrogen, biomass, etc. are not totally developed to replace completely the energy generation from fossil fuels [2], the capture of generated carbon dioxide for its subsequent sequestration has become the more favorable short-term solution.

Chemical looping combustion (CLC) is one of the most promising technologies for the capture of carbon dioxide $\left(\mathrm{CO}_{2}\right)$ at low cost, with a high efficiency. This system employs a solid oxygen-carrier (OC), typically a metal oxide, instead of air as the oxygen source for combustion. The flue gas contains mainly $\mathrm{CO}_{2}$ and water. Since it does not contain nitrogen, the $\mathrm{CO}_{2}$ separation, which has the major cost for $\mathrm{CO}_{2}$ capture can be avoided.

As illustrated in Figure 1, in CLC, the solid oxygen-

"Corresponding author. carrier is circulated in a loop between two reactors. In combustion reactor, solid oxygen carrier reacts with fuel to produce mainly carbon dioxide and water. Those compounds can be easily separated by water condensation.

The reduced oxygen carrier is then transported to the air reactor where it is oxidized with heat releases. The exhaust gas from air reactor is composed only of oxygen depleted air. The overall reactions of the oxygen carrier can be written as:

In combustion reactor:

$$
\begin{aligned}
& \mathrm{C}_{a} \mathrm{H}_{2 b}+(2 a+b) \mathrm{Me}_{x} \mathrm{O}_{y} \\
& \rightarrow a \mathrm{CO}_{2}+b \mathrm{H}_{2} \mathrm{O}+(2 a+b) \mathrm{Me}_{x} \mathrm{O}_{y-1}
\end{aligned}
$$

In air reactor:

$$
\mathrm{Me}_{x} \mathrm{O}_{y-1}+1 / 2 \mathrm{O}_{2} \rightarrow \mathrm{Me}_{x} \mathrm{O}_{y}
$$

The total amount of heat resulting from reactions (1.1) and (1.2) does not change from a conventional combustion where the fuel is in direct contact with air. Consequently, CLC process has the advantage of producing a 


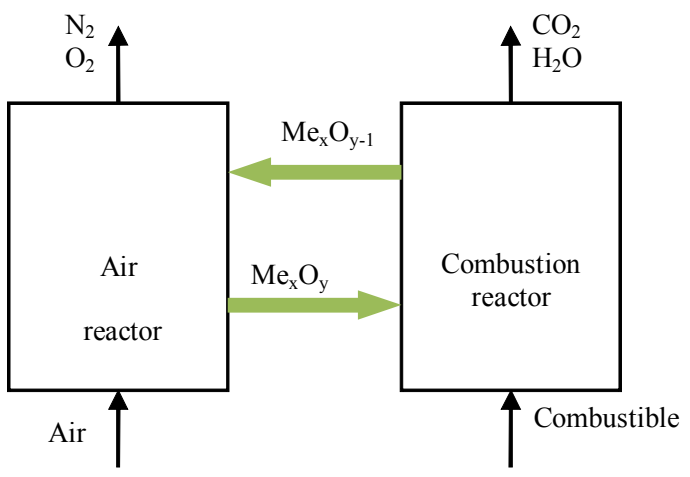

Figure 1. Reactor scheme of the CLC process.

pure stream of $\mathrm{CO}_{2}$ without additional energy for gases separation.

The use of CLC was firstly introduced by Ishida [3] and developed for gaseous fuels. The earlier research on CLC focused on the selection of appropriate oxygen carriers, as one of the most critical steps. Several possible oxygen carriers have been tested: metal oxides based on nickel, copper, iron, manganese, cobalt or even mixedoxide oxygen carriers with various support materials (alumina, bentonite, rutile, etc.) [4-15]. It has been agreed that $\mathrm{NiO}$ and $\mathrm{CuO}$ were the most reactive metal oxides. However, $\mathrm{Cu}$ sinters at $950^{\circ} \mathrm{C}$ which limits the application at high temperature [5] and $\mathrm{Ni}$ is expensive and may generate detrimental environmental (including health and safety) effects. The Fe exhibits a moderate activity with a partial conversion of $\mathrm{Fe}^{3+}$. Leion et al. $[14,15]$ found that iron minerals are a good low cost alternative to synthetic oxygen carrier while keeping most of the suitable characteristics in CLC process. Ilmenite has proved to be the most interesting iron ores [16-18].

Ilmenite is a mineral composed of crystalline titanium-iron oxide $\left(\mathrm{FeTiO}_{3}\right)$. The $\mathrm{Fe}-\mathrm{Ti}-\mathrm{O}$ system including ilmenite can take several solid solutions depending on the stoichiometry between iron and titanium oxides. Nell et al. [19] have established that in oxidized ilmenite, two solid phases can be present; the first one has the $\mathrm{M}_{2} \mathrm{O}_{3}$ ilmenite structure, where $\mathrm{FeTiO}_{3}$ and $\mathrm{Fe}_{2} \mathrm{O}_{3}$ are miscible within certain limits and the second is the $\mathrm{TiO}_{2}$ rutile which is formed according to:

$$
2 \mathrm{FeTiO}_{3}+1 / 2 \mathrm{O}_{2} \rightarrow \mathrm{Fe}_{2} \mathrm{O}_{3}+2 \mathrm{TiO}_{2}
$$

Rutile crystallites are located outside of the $\mathrm{M}_{2} \mathrm{O}_{3}$ structure and free cation sites are generated because of the addition of oxygen anionic sites. If the oxidation continues, a second phase with $\mathrm{M}_{3} \mathrm{O}_{5}$ structure appears. There is a certain miscibility reported between $\mathrm{FeTi}_{2} \mathrm{O}_{5}$ $\left(\mathrm{Fe}^{2+}\right)$ and $\mathrm{Fe}_{2} \mathrm{TiO}_{5}\left(\mathrm{Fe}^{3+}\right)$, and rutile is formed during the oxidation:

$$
2 \mathrm{FeTi}_{2} \mathrm{O}_{5}+1 / 2 \mathrm{O}_{2} \rightarrow \mathrm{Fe}_{2} \mathrm{TiO}_{5}+3 \mathrm{TiO}_{2}
$$

Besides, Briggs et al. [20] have found that pre-oxida- tion of mineral increases the rate reduction of samples.

Once the mineral is reduced, rutile is formed and appears outside of the iron-containing phases. During the oxidation of the reduced mineral, the original ilmenite phase is reformed and moves back into the original structure.

The industrial feasibility of CLC process for gas fuels has been successfully tested in fluidized reactor units ranging from $300 \mathrm{~W}-500 \mathrm{~kW}$ using natural gas or syngas [21-26]. These reactors have the advantage of earning excellent transport properties. However, when used with iron oxide as oxygen carrier, this reactor configuration does not allow the conversion of $\mathrm{Fe}^{3+}$ to $\mathrm{Fe}^{0}$ because of high partial pressure ratio $\mathrm{CO}_{2} / \mathrm{CO}$ (see Figure 2).

According to several authors [27,28], the reduction of ilmenite to metallic iron avoids to oxidize completely the methane to the state of $\mathrm{CO}_{2}$. Even if this inconvenience is confirmed, it is possible to take advantage of the high capacity of oxygen transfer of the ilmenite in a reactor implementation which ensures a complete conversion of methane into $\mathrm{CO}_{2}$; for Instance, if a countercurrent (Figure 3) moving bed is used, thermodynamic equilib-

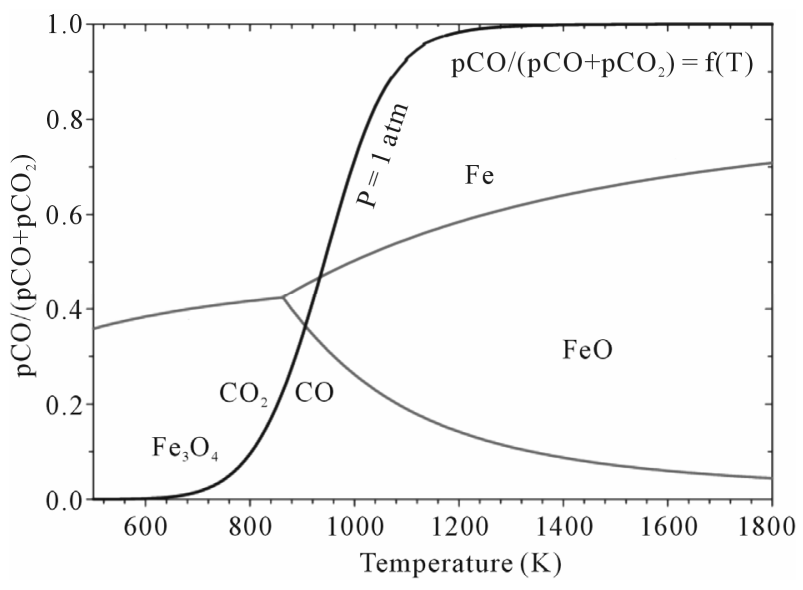

Figure 2. Thermodynamics of the $\mathrm{Fe}_{2} \mathrm{O}_{3}$ reaction with $\mathrm{CO}$.

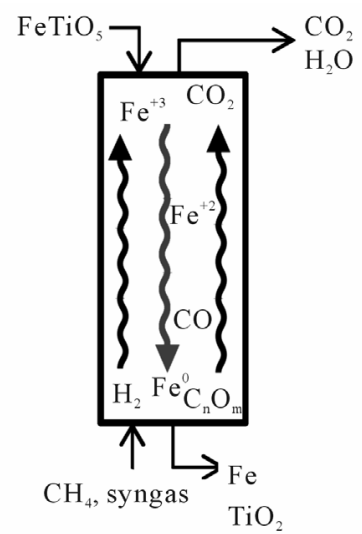

Figure 3. Countercurrent moving bed schema for using in the CLC process with Fe-Ti-O oxides. 
rium is shifted and higher conversions of iron oxides can be achieved. Thus, a higher oxygen transfer capacity takes place meaning in a significantly less amount of oxygen carrier and smaller reactor configuration. Previous work [29] in moving bed flow has demonstrated the plug flow behavior of the solids and the uniform porosity distribution into the bed. These characteristics are suitable to a good solid-gas contact and therefore a good reactivity on CLC can be expected.

Regarding, the reducing agents, most of available literature describes ilmenite reduction using gasification products (hydrogen, carbon monoxide), or carbon [16], [30-33] but only a limited number of studies have included the methane among these agents. Flamant et al. [34] indicated that from a thermodynamic point of view, the ilmenite reduction is more favorable using methane than using $\mathrm{H}_{2}$ or $\mathrm{CO}$ as reducing agent. From a kinetic point of view, Adanez et al. [16] have shown that ilmenite has a decreasing reactivity towards gas combustibles as: $\mathrm{H}_{2}>\mathrm{CO}>\mathrm{CH}_{4}$.

Methane sources are diverse. It represents the major component of natural gas. It is also released into the primary thermal decomposition of fuel at amounts as higher as $20 \%$ for biomass fuels [34]. Moreover, the results obtained by Leion [14], Cuadrat [33-35] and Berguerand [36-38], when using solid fuels, unconverted methane is found in the exhaust gases from fuel reactor. Thereby, the comprehension of methane reactivity must be deepened into the global behavior of CLC process.

The aim of this paper is to contribute in understanding of ilmenite reduction using methane as a reducing agent. This study uses principally TG-DT analysis to evaluate the reactivity of ilmenite in order to be applied in a countercurrent moving bed. XR diffraction is used as a technique for solids characterization. Reactivity is discussed as a function of temperature and gas composition. The influence of carbon deposition and ilmenite behavior in cyclical reduction-oxidation are also investigated.

\section{Experimental Section}

\subsection{Characterization of Materials}

The raw ilmenite as well as reacted ilmenite were characterized by:

- X-ray diffraction using a powder X-ray diffractometer (XRD) Inel CPS 120 equipped with iron anticathode with filtered radiation $\lambda=1.936 \AA$ and an ethane ionization curved detector allowing angles to be read simultaneously in the range $2 \theta=5^{\circ}-120^{\circ}$.

- Measurement of BET specific surface area which is taken in a conventional static volume apparatus (Micromeritics ASAP 2020) operating with $\mathrm{N}_{2}$ adsorption at $-196^{\circ} \mathrm{C}$. The samples were initially degassed during 3 hours at $300^{\circ} \mathrm{C}$.
- Granulometric analysis established with a Mastersize $\mathrm{X}$ laser diffraction analyzer.

- He pycnometry using a Accupyc 1330 de Micromeretics Instruments Inc.

\subsection{Reactivity Test}

Raw ilmenite was pre-oxidized under air atmosphere at $1000^{\circ} \mathrm{C}$ for 24 hours. Reactivity experiments were performed using SETARAM 92 coupled TG-DT analyzer. Samples of $20 \pm 2 \mathrm{mg}$ of pre-oxidized ilmenite were placed in a platinum crucible and preheated (heating rate $20^{\circ} \mathrm{C} / \mathrm{min}$ ) under $\mathrm{N}_{2}$ atmosphere to the desired reaction temperature ranging from $700^{\circ} \mathrm{C}$ to $1000^{\circ} \mathrm{C}$. Then, it was exposed to a reducing gas $\left(\mathrm{CH}_{4}\right)$ or to an oxidizing gas (air) until the end of the reaction. Throughout the reduction/oxidation reactions, the weight and the heat flow of the sample was recorded continuously.

The gas flow rate for all periods and cycles was 30 $\mathrm{mL} / \mathrm{min}$ (at $1 \mathrm{bar}$ and $25^{\circ} \mathrm{C}$ ). To determine the influence of water steam on carbon deposition, a bubbler was used to saturate the inlet reactive gas with steam. According to the selected temperature of the bubbler, the steam ratio was adjusted from $0 \%$ to $20 \%$.

To determine the stability of ilmenite and its reactivity, successive reductions and oxidations were conducted over 32 cycles at $900^{\circ} \mathrm{C}$. The solid was exposed to methane and air alternately to simulate the CLC process cycle. To avoid mixing between the oxidation and reduction gases, the reactor was flushed with nitrogen for 3 minutes after each stage of the cycle.

\section{Results and Discussion}

\subsection{Characterization of Ilmenite}

XRD patterns of the initial ilmenite sample and pre-oxidized ilmenite (Figure 4) suggest that $\mathrm{FeTiO}_{3}$ is the only crystalline phase present in the raw ilmenite. After oxidation, a mixture of two crystalline phases, ilmenite $(\mathrm{FeTiO})$, pseudobrookite $\left(\mathrm{Fe}_{2} \mathrm{TiO}_{5}\right)$ and $\mathrm{TiO}_{2}$ are de-

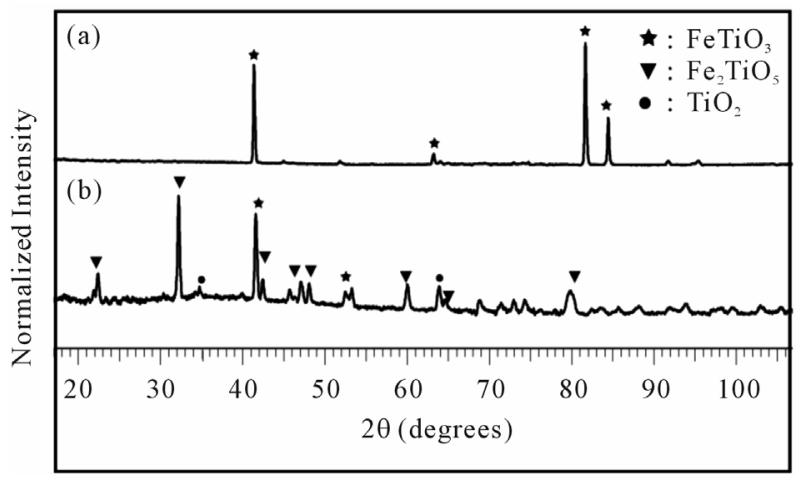

Figure 4. XRD patterns of (a) raw ilmenite and (b) preoxidized ilmenite. 
tected. Other characteristics of the raw ilmenite can be found in Table 1 in Section 3.5, later.

\subsection{Ilmenite Reactivity}

Ilmenite reactivity was investigated during reduction and oxidation separately. Since the oxidized mineral is a complex mixture of $\mathrm{Fe}_{2} \mathrm{TiO}_{5}, \mathrm{FeTiO}_{3}$ and $\mathrm{TiO}_{2}$ (Figure 4(b)), assuming that $\mathrm{TiO}_{2}$ is an inert material that is not affected by the reduction and the mass loss is only due to the iron cations reduction, the following reduction reactions can be expected to occur:

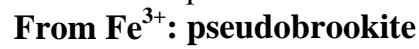

$$
\begin{aligned}
& \mathrm{Fe}_{2} \mathrm{TiO}_{5}\left(\mathrm{Fe}_{2} \mathrm{O}_{3}+\mathrm{TiO}_{2}\right) \\
& 6 \mathrm{Fe}_{2} \mathrm{TiO}_{5}+6 \mathrm{TiO}_{2}+1 / 2 \mathrm{CH}_{4} \\
& \rightarrow 4 \mathrm{Fe}_{3} \mathrm{Ti}_{3} \mathrm{O}_{10}+1 / 2 \mathrm{CO}_{2}+2 \mathrm{H}_{2} \mathrm{O} \\
& 4 \mathrm{Fe}_{2} \mathrm{TiO}_{5}+4 \mathrm{TiO}_{2}+\mathrm{CH}_{4} \\
& \rightarrow 8 \mathrm{FeTiO}_{3}+\mathrm{CO}_{2}+2 \mathrm{H}_{2} \mathrm{O} \\
& \mathrm{Fe}_{2} \mathrm{TiO}_{5}+\mathrm{CH}_{4} \rightarrow 8 \mathrm{Fe}+4 \mathrm{TiO}_{2}+3 \mathrm{CO}_{2}+6 \mathrm{H}_{2} \mathrm{O} \\
& \text { From } \mathrm{Fe}^{2+} \mathbf{F e}^{3+}: \quad \mathrm{Fe}_{3} \mathrm{Ti}_{3} \mathrm{O}_{10}\left(\mathrm{Fe}_{3} \mathrm{O}_{4}+3 \mathrm{TiO}_{2}\right) \\
& 2 \mathrm{Fe}_{3} \mathrm{Ti}_{3} \mathrm{O}_{10}+0.5 \mathrm{CH}_{4} \rightarrow 6 \mathrm{FeTiO}_{3}+\mathrm{CO}_{2}+\mathrm{H}_{2} \mathrm{O} \\
& \mathrm{Fe}_{3} \mathrm{Ti}_{3} \mathrm{O}_{10} \rightarrow 3 \mathrm{Fe}+3 \mathrm{TiO}_{2}+\mathrm{CO}_{2}+2 \mathrm{H}_{2} \mathrm{O}
\end{aligned}
$$

From $\mathrm{Fe}^{2+}$ : Ilmenite $\mathrm{FeTiO}_{3}\left(\mathrm{FeO}+\mathrm{TiO}_{2}\right)$

$$
4 \mathrm{FeTiO}_{3}+\mathrm{CH}_{4} \rightarrow 4 \mathrm{Fe}+4 \mathrm{TiO}_{2}+\mathrm{CO}_{2}+2 \mathrm{H}_{2} \mathrm{O}
$$

During the ilmenite reduction at $900^{\circ} \mathrm{C}$ with pure $\mathrm{CH}_{4}$, two different rates of weight loses associated with two simultaneous endothermic DT peaks are observed (see Figure 5). The second reaction is more endothermic and faster than the first one. This behavior reveals the succession of at least two different reactions. When the weight loss reaches about $10 \%$, the increase of the sample weight is observed.

During the ilmenite reduction, different phenomena should be taken into account. In fact, the TG signal represents the overall weight variation of the sample. It results of the signals superposition from simultaneous reactions: on one hand, the reduction of pre-oxidized il-

Table 1. Characterization of raw and reacted ilmenite.

\begin{tabular}{ccc}
\hline & $\begin{array}{c}\text { Pre-oxidized } \\
\text { ilmenite }\end{array}$ & 5 cycles reduced ilmenite \\
\hline $\begin{array}{c}\text { XRD } \\
\text { (main species) }\end{array}$ & $\begin{array}{c}\mathrm{Fe}_{2} \mathrm{TiO}_{5}, \mathrm{TiO}_{2}, \\
\mathrm{FeTiO}_{3}\end{array}$ & $\mathrm{~T}<800^{\circ} \mathrm{C}: \mathrm{FeTiO}_{3}, \mathrm{TiO}_{2}, \mathrm{Fe}_{3} \mathrm{O}_{4}$ \\
True density & $4575 \mathrm{~kg} / \mathrm{m}^{3}$ & $4110 \mathrm{~kg} / \mathrm{m}^{3}$ \\
Porosity & $16.07 \%$ & $36.72 \%$ \\
Particle diameter & $25-300 \mu \mathrm{m}$ & $25-300 \mu \mathrm{m}$ \\
BET surface & $0.10 \mathrm{~m}^{2} / \mathrm{g}$ & $0.21 \mathrm{~m}^{2} / \mathrm{g}$ \\
\hline
\end{tabular}

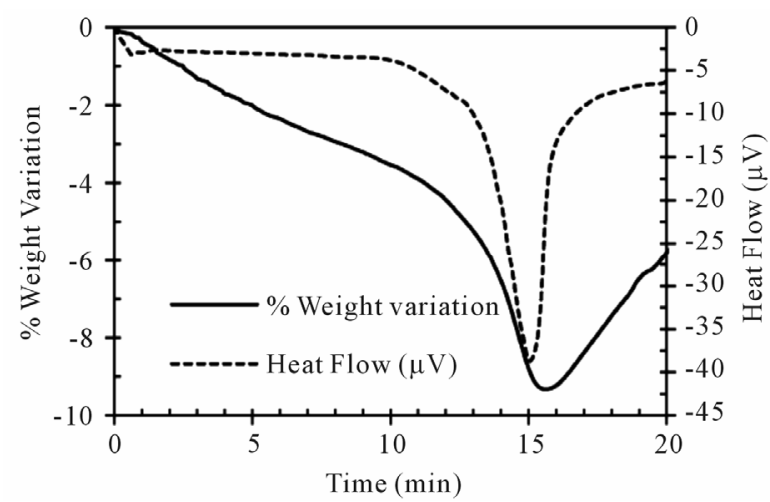

Figure 5. TG-DT analysis during pre-oxidized ilmenite reduction at $900^{\circ} \mathrm{C}$.

menite and on the other hand the deposition of carbon due to the methane decomposition. Initially, the ilmenite reduction is accompanied by the weight loss of the sample, however, when most of the available oxygen in the mineral is exhausted, the carbon resulting from the methane decomposition accumulates on the sample. In other words, when carbon deposition prevails over ilmenite reduction, the weight variation becomes positive.

Two explanations can justify this behavior. On one hand, knowing that the iron group ( $\mathrm{Fe}, \mathrm{Ni}, \mathrm{Co}$ ) is the traditional catalyst of the methane decomposition and that the iron forms exactly during the second stage of ilmenite reduction, one expect that it comes along by a carbon deposition. On the other hand, the carbon itself can contribute in the reduction of the ilmenite and thus, as long as the metallic iron is not reached, the carbon cannot accumulate on the sample. It is also possible that both described mechanisms participate simultaneously to prevent the carbon deposition during the beginning of the reduction.

The whole reaction is over in about 20 minutes. This is indicated by the coming back of the DT signal to the baseline. The weight variation obtained in thermogravimetric tests can directly be associated with the oxygen transfer capacity of the carrier $\left(R_{O}\right)$ from the relationship:

$$
R_{\mathrm{O}}=\frac{m_{\mathrm{ox}}-m_{\mathrm{red}}}{m_{\mathrm{ox}}}
$$

where $m_{\mathrm{ox}}$ and $m_{r}$ are respectively the mass of the most oxidized and the most reduced forms of the oxygen carrier. The oxygen transfer capacity is about $9.5 \%$ for this test $\left(900^{\circ} \mathrm{C}\right)$. Theoretical oxygen transport capacities from total conversion of reactions (3.1) to (3.6) are summarized in Table 2. Oxidation of ilmenite was carried out using air as oxidizing agent. Results from test at $900^{\circ} \mathrm{C}$ are shown in Figure 6. They confirm the validity of the sequential reactions observed during the reduction test. Once again the thermogravimetric signal is overlapping the response of two phenomena: the oxidation of the 
Table 2. Theoretical oxygen transport capacity from ilmenite at different oxidation states of iron.

\begin{tabular}{cccc}
\hline From/To & $\mathrm{Fe}_{3} \mathrm{Ti}_{3} \mathrm{O}_{10}$ & $\mathrm{FeTiO}_{3}$ & $\mathrm{Fe}+\mathrm{TiO}_{2}$ \\
\hline $\mathrm{Fe}_{2} \mathrm{TiO}_{5}$ & $1.7 \%$ & $5.1 \%$ & $20 \%$ \\
$\mathrm{Fe}_{3} \mathrm{Ti}_{3} \mathrm{O}_{10}$ & - & $3.4 \%$ & $13.6 \%$ \\
$\mathrm{FeTiO}_{3}$ & - & - & $10.5 \%$ \\
\hline
\end{tabular}

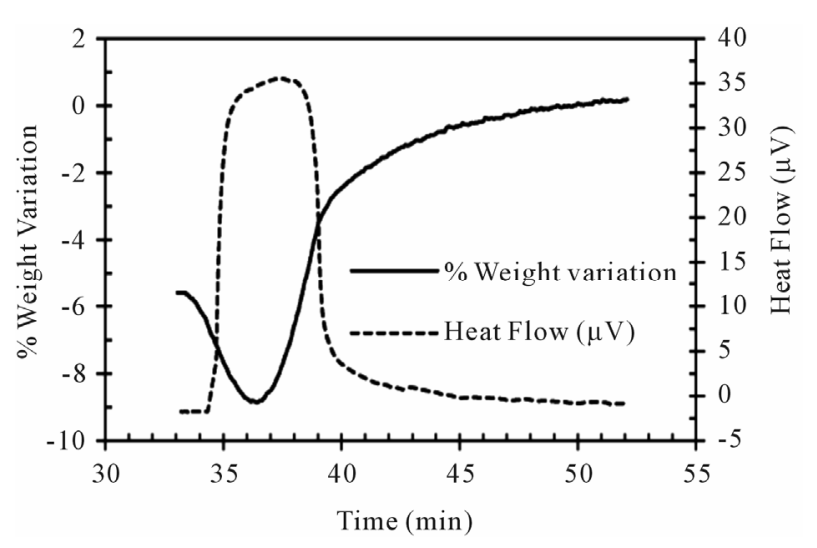

Figure 6. TG-DT analysis during ilmenite oxidation at $900^{\circ} \mathrm{C}$.

reduced ilmenite (resulting in a mass decrease) and this of the deposited carbon (resulting in a mass increase).

The DT signal corresponds to the exothermic behavior of the overall reactions including the carbon combustion. At the end of oxidation the sample weight is slightly higher than before reduction. Thus, the $R_{O}$ is enhanced over the first reduction-oxidation cycle.

\subsection{Temperature Effect}

The reduction behavior of pre-oxidized ilmenite was studied at $700^{\circ} \mathrm{C}, 800^{\circ} \mathrm{C}, 900^{\circ} \mathrm{C}$ and $1000^{\circ} \mathrm{C}$. Reduced samples were characterized by XDR in order to have an idea of the nature of formed species. The temporal weight losses at these four temperatures are presented in Figure 7 and the corresponding difractogrammes in Figure 8. As expected, the reduction rates increases with increasing temperature.

The time to reach the maximum weight loss during the reduction has been decreased by 50 times between $700^{\circ} \mathrm{C}$ and $1000^{\circ} \mathrm{C}$ and $R_{O}$ passed from $1.8 \%$ to $12 \%$.

At $700^{\circ} \mathrm{C}$, the maximal weight loss was reached after 250 minutes. The reduction profile did not show a significant carbon deposition after $500 \mathrm{~min}$ of reaction.

The XRD analysis (Figure 8(d)) revealed that the principal products of the pre-oxidized ilmenite (mostly $\mathrm{Fe}_{2} \mathrm{TiO}_{5}$ ) reduction are $\mathrm{FeTiO}_{3}, \mathrm{Fe}_{3} \mathrm{O}_{4}$ and $\mathrm{TiO}_{2}$ at this temperature. The fact that there is no change in the slope of the weight loss curve indicates a one single step reaction. Both results from TG and XRD analysis are consistent with the reactions (3.1) and (3.2), showing a partial

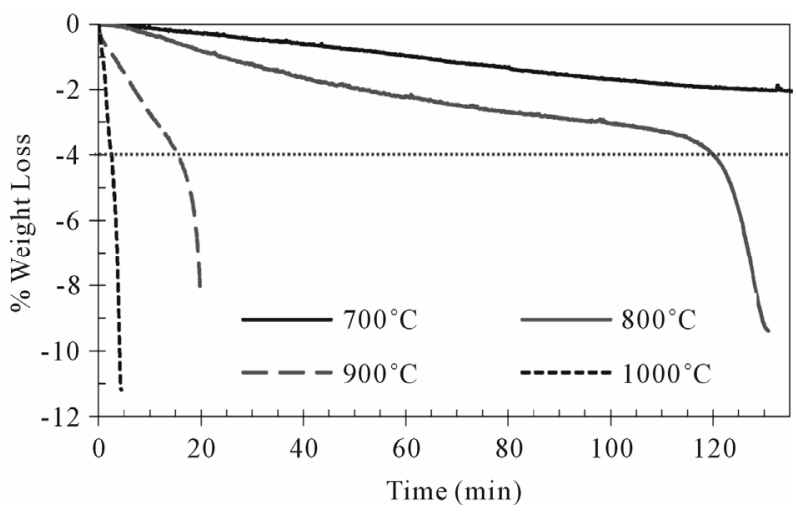

Figure 7. Effect of temperature on ilmenite reduction with pure methane (from $700^{\circ} \mathrm{C}$ to $1000^{\circ} \mathrm{C}$ ).

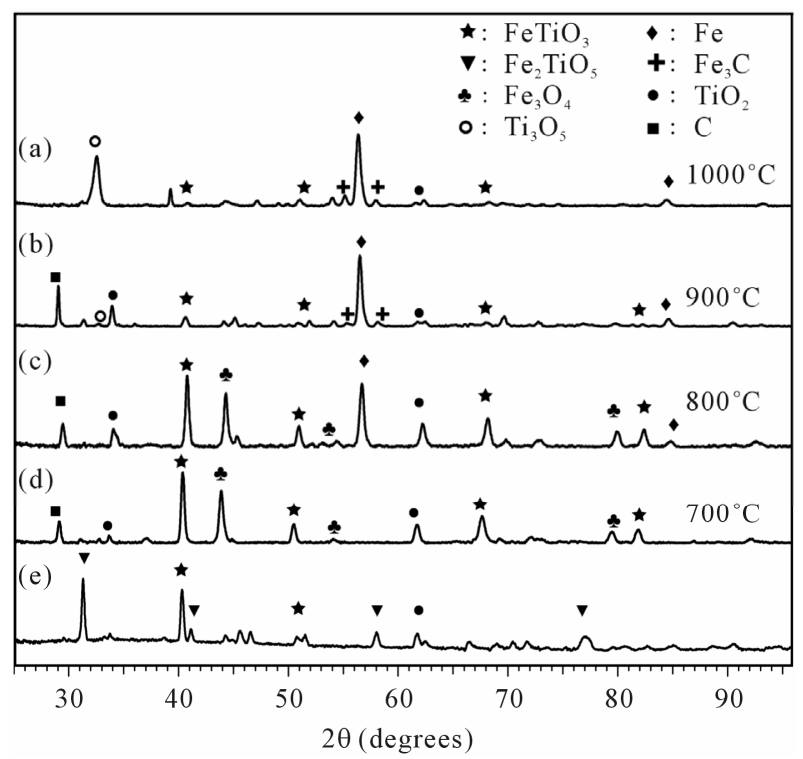

Figure 8. XRD patterns for reduced ilmenite with pure methane at different temperatures (from $700^{\circ} \mathrm{C}$ at $1000^{\circ} \mathrm{C}$ ).

reduction of $\mathrm{Fe}^{3+}$ into $\mathrm{Fe}^{2+}$.

$$
\begin{aligned}
& 6 \mathrm{Fe}_{2} \mathrm{TiO}_{5}+6 \mathrm{TiO}_{2}+1 / 2 \mathrm{CH}_{4} \\
& \rightarrow 4 \mathrm{Fe}_{3} \mathrm{Ti}_{3} \mathrm{O}_{10}+1 / 2 \mathrm{CO}_{2}+2 \mathrm{H}_{2} \mathrm{O} \\
& \left(R_{O}=1.7 \%\right) \\
& 4 \mathrm{Fe}_{2} \mathrm{TiO}_{5}+4 \mathrm{TiO}_{2}+\mathrm{CH}_{4} \\
& \rightarrow 8 \mathrm{FeTiO}_{3}+\mathrm{CO}_{2}+2 \mathrm{H}_{2} \mathrm{O} \\
& \left(R_{O}=5.1 \%\right)
\end{aligned}
$$

At temperature higher than $800^{\circ} \mathrm{C}$, reduction takes place in a two stages mechanism and a variation in the curves slopes is noted around $4 \%$ of weight loss. As presented in previous section, the first stage has a lower reduction rate than the second one.

These results are in disagreement with those reported by Abad et al. [28] indicating a higher rate for the first reduction step. The divergence could be caused by the 
lower methane concentration used in their work. Comparison of the measured weight loss with the theoretical values of $\mathrm{R}_{\mathrm{O}}$ indicates that the first reaction is related to the complete reduction of $\mathrm{Fe}_{2} \mathrm{TiO}_{5}$ to $\mathrm{FeTiO}_{3}$, just as in reduction at $700^{\circ} \mathrm{C}$ (reaction 3.2). This result is confirmed by XRD (Figures 8(a)-(c)).

In the second stage, the metallic iron formation was proved and coupled to the disappearance of most of $\mathrm{Fe}^{2+}$ phases and the reaction (3.6) thereafter can be presumed. The final state of the reduction varies with the temperature and shows an incomplete reduction from $\mathrm{Fe}^{2+}$ to $\mathrm{Fe}^{0}$. The higher reduction states are obtained at $1000^{\circ} \mathrm{C}$.

$$
\begin{aligned}
& 4 \mathrm{FeTiO}_{3}+\mathrm{CH}_{4} \rightarrow 4 \mathrm{Fe}+4 \mathrm{TiO}_{2}+\mathrm{CO}_{2}+2 \mathrm{H}_{2} \mathrm{O} \\
& \left(\mathrm{R}_{\mathrm{O}}=10.5 \%\right)
\end{aligned}
$$

Besides, others phases have been detected; a graphite peak reveals the presence of deposed carbon in the overall range of studied temperatures. The migration of the carbon particles within the crystal lattice of mineral was evidenced by the apparition of the $\mathrm{Fe}_{3} \mathrm{C}$ phase from $900^{\circ} \mathrm{C}$.

This formation was increased with temperature. At $1000^{\circ} \mathrm{C}$, the apparition of a reduced titanium oxide form $\left(\mathrm{Ti}_{3} \mathrm{O}_{5}\right)$ is observed as well, besides of the loss of $\mathrm{TiO}_{2}$ which is no longer visible. It indicates that ilmenite reactivity could not be completely approached by the only iron oxides reactivity and that mineral must be studied as such. The weight variation due to these parallel reactions is involved into the overall signal of TGA.

\subsection{Effect of Carbon Deposition}

As presented previously, carbon deposition is observed in all tests at temperature higher than $700^{\circ} \mathrm{C}$. Carbon deposition on the solid oxide is a fatal problem, because it lowers the mineral activity and shortens its life. Furthermore, it could diminish the $\mathrm{CO}_{2}$ capture in the CLC process. To determine the impact of this deposition over the ilmenite reduction, steam water was added in the feed gas. Temperature was fixed at $1000^{\circ} \mathrm{C}$ and steam was generated by saturating the inlet courant using a bubbler.

Figure 9 shows the results from reduction test at $0 \%$ and $20 \%$ steam, it can be observed that for the first stage of reduction, the bearing of both tests is quite similar and there is no difference between the reduction rates. $R_{O}$ is slightly modified by the water addition; this variation is in agreement with the diminution of deposed carbon.

In the second stage, the reduction rate decreases when the steam is added. The reduction of the reduction rate is probably due to the partial pressure decrease of methane. The whole behavior of the curves permits to affirm that over the first stage of reduction there is no carbon deposition, which is only observed when the available oxygen in the mineral decreases. The addition of water steam enables a slight higher global weight loss. At test conditions, steam water did not avoid carbon deposition completely.

The effect of carbon deposition over ilmenite during reduction was also studied. As it can be observed in Figure 5, after the solid has reached its maximal weight loss, the deposition prevails over ilmenite reduction. Figure 10 shows the behavior corresponding to the only carbon deposition phenomena (positive slope from reduction curves obtained from TGA).

It is also shown in this Figure for a comparison, a carbon deposition obtained on an inert solid ( $\alpha$-Alumina) instead of the ilmenite. It can be noted that the carbon deposition is favored in the presence of the reduced ilmenite, acting like a catalyst for methane cracking due to its iron content. The addition of $20 \%$ of water on reactive gas reduced the carbon deposition by a factor of 30 .

\subsection{Cyclical Test}

Cyclical test was performed in order to investigate the behavior of ilmenite in a normal cycle of CLC process and the reactivity, deactivation and renewability of the

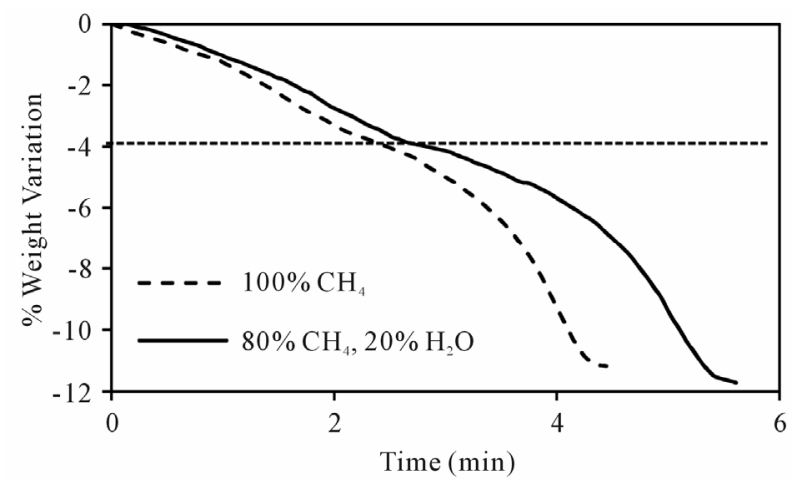

Figure 9. Effect of steam addition on ilmenite reduction at $1000^{\circ} \mathrm{C}$.

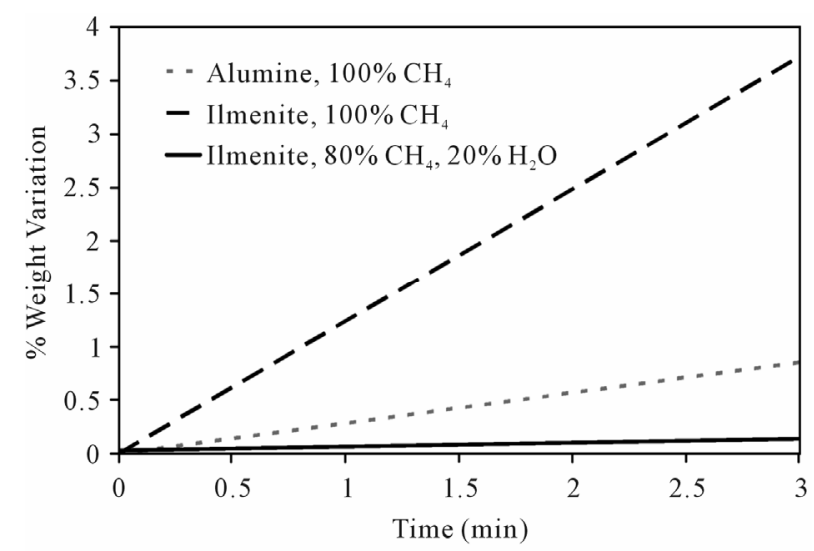

Figure 10. Weight variation due to carbon deposition over reduced ilmenite and alumina at different compositions of feed gas at $1000^{\circ} \mathrm{C}$. 
mineral. Tests were performed over 32 cycles of reduction-oxidation with TG-TD analysis. Temperature was fixed at $900^{\circ} \mathrm{C}$, air was used as oxidizing agent and pure methane was used as reducing agent. Reaction time during oxidation was set by the stabilization of the maximum weight in the case of oxidation. Reduction was considered achieved and the methane feed was stopped when the lowest mass of the sample was reached and carbon deposition begins to increase the sample mass.

Figure 11 represents the sample weight variation during the first 10 cycles for pre-oxidized ilmenite.

At first, ilmenite reacts slowly and reaches a weight variation of $9.5 \%$. This variation is considered to be entirely due to oxygen transfer. When there was not a high amount of available oxygen in the mineral, the beginning of carbon deposition was observed and the feed of reducing gas was stopped.

After the sample is flushed with nitrogen, oxidation takes place and the TG signal has come back to initial value. There is however a phase of solid activation during the first 5 redox cycles, where both weight lost in reduction and gained in oxidation are increased. The weight loss stabilizes at an average value of $10.8 \%$ for reduction reaction and it can be also observed a growth of $0.8 \%$ of capacity of oxidation.

Both rate of reaction and oxygen transfer capacity have been improved despite the carbon deposition; this results are consistent with Cuadrat et al. experiences [39] carried out at a lower methane concentration. The improvement of ilmenite performance is associated with the porosity and reactive surface development on metallic solid. In fact, the reaction between oxygen from ilmenite and methane allows the formation of lacks in the crystalline lattice and thus enlarges the specific surface available to react. The results from characterization of reacted ilmenite exhibit a porosity development. Low values of BET surface area were measured, but a considerable increase was observed after 5 cycles of reduction-oxidation. The ilmenite properties after 32 reduction oxidation did not show significant differences compared to 5 cycles characteristics.
Figure 12 shows weight variation with time during the reduction of pre-oxidized ilmenite after different consecutive cycles. Like for the increase of oxygen capacity transfer, successive redox cycles enhance the reaction rate of ilmenite reduction. The reactivity rises around 9 times over 30 cycles.

\subsection{Discussion}

The influence of the studied parameters (composition, temperature) on ilmenite reduction and on carbon deposition intended evaluate the ilmenite performance as an oxygen carrier in order to be used in countercurrent moving bed CLC process. A particular attention is granted to the phase of ilmenite reduction to look for the conditions allowing a high rate of reaction, a high oxygen transfer capacity and a minimization of the carbon deposit. Even if the analysis of products resulting from the reduction of the ilmenite was not realized, it is important for the CLC process to ensure that methane is mainly converted into $\mathrm{CO}_{2}$.

The study of the complete reduction of Fe-Ti-O system until the most reduced oxidation states of iron shows the great advantage in terms of the extended oxygen transport capacity from the ore, the reducibility tests have exposed that when high methane concentrations and high temperatures are fixed, the mineral can loss of $12 \%$ of their initial weight. This value corresponds to $60 \%$ of the total amount of oxygen present in the ore as the iron oxides forms, meaning $80 \%$ of the oxygen transfer capacity when the reaction schema follows the mechanism presented above $\left(\mathrm{FeTiO}_{5} \rightarrow \mathrm{FeTiO}_{3} \rightarrow \mathrm{Fe}+\mathrm{TiO}_{2}\right.$ ). (see Table 2). The gases analysis was not performed, but it is known from thermodynamics that the second reduction step, leads to a partial oxidation of methane to $\mathrm{CO}$. This equilibrium can be shifted by using a countercurrent moving bed, and in this way a complete oxidation into $\mathrm{CO}_{2}$ can be reached. These experiences will be the issue of future works. Test cycle demonstrate that after extent iron reductions is achieved (the case into a countercurrent moving reactor), the physicochemical structure change without losing in terms of activity of the mineral.
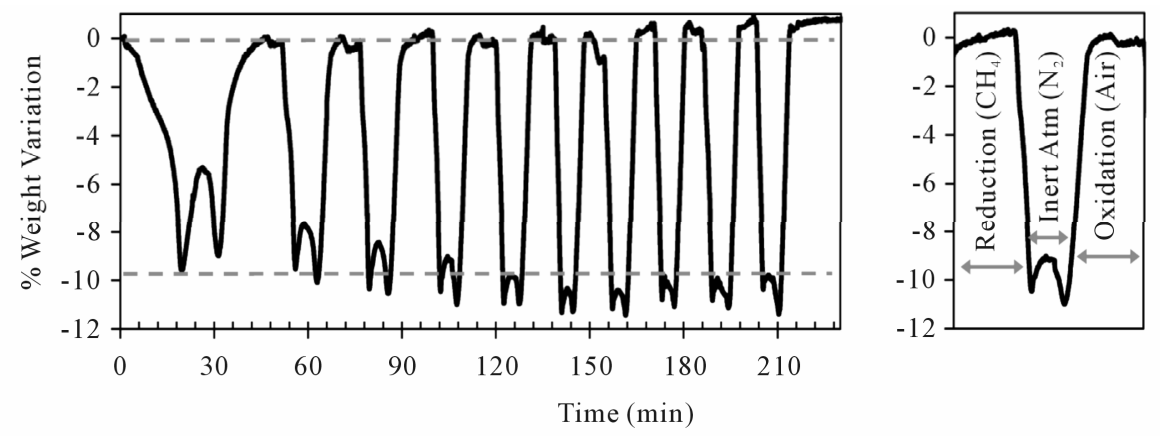

Figure 11. Weight variations during reduction-oxidation cycles using TG analysis from pre-oxidized ilmenite. 


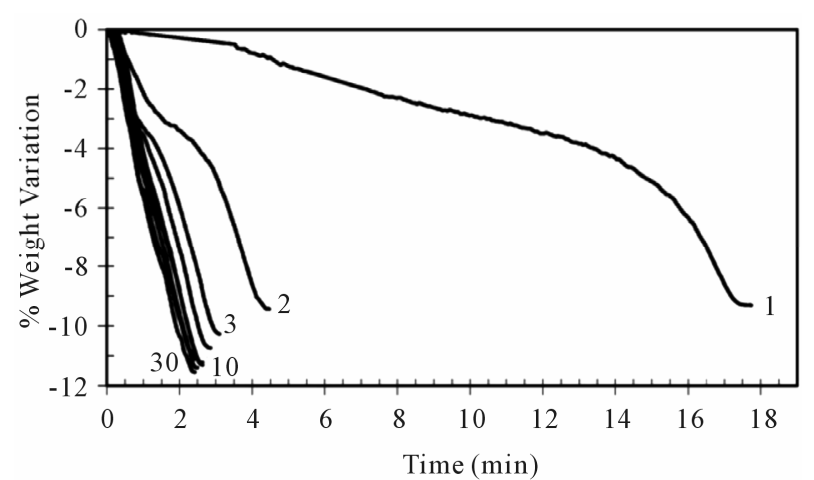

Figure 12. Weight variation in several cycles $(1,2,3,4,5,10$, 20,30 ) of ilmenite reduction.

This study has also been established that the carbon deposition due to methane decomposition was present in all tests over $800^{\circ} \mathrm{C}$. Its deposition rate was favored because of the ilmenite use. However, it has been identified that such deposition is favorable just when the oxygen capacity from the ore is exhausted.

On the other hand it has been verified that the presence of water significantly reduces this phenomenon, even in quantities as low as $20 \%$. Anyway since water is a product of the reaction of reduction of ilmenite, this phenomenon can be avoided in the industrial realization of the process.

\section{Conclusions}

The reduction of pre-oxidized ilmenite using methane as reducing agent has been examined by TG-DT analysis. Several conclusions in connection with the chemical looping combustion can be drawn. Oxygen transfer capacity of mineral is enhanced with increasing temperature and concentration of reduction agent. The global reaction rate has increased by 50 times when temperature was increased from $700^{\circ} \mathrm{C}$ to $1000^{\circ} \mathrm{C}$. Two stages of reduction were observed during the ilmenite reduction at temperatures higher than $800^{\circ} \mathrm{C}$. These stages were confirmed by XRD. During the first stage, reduction takes place mainly as $\mathrm{Fe}_{2} \mathrm{TiO}_{5} \rightarrow \mathrm{FeTiO}_{3}$ and was characterized by slower rates than second one. In second stage the ilmenite reduction takes place mainly as $\mathrm{FeTiO}_{3} \rightarrow \mathrm{Fe}+$ $\mathrm{TiO}_{2}$. At $1000^{\circ} \mathrm{C}$, a reduced titanium oxide form $\left(\mathrm{Ti}_{3} \mathrm{O}_{5}\right)$ is observed simultaneously with the loss of $\mathrm{TiO}_{2}$ which is no longer visible. It indicates that ilmenite oxygen transfer capacity in ultimate state of reduction is not only due to iron oxides reactivity but also to titanium oxide.

Ilmenite plays catalyst role in methane decomposition. However, the carbon deposition was confirmed to take place only at the end of the second reduction stage when most of oxygen available on mineral was depleted. The ilmenite renewability was confirmed over 30 cycles of reduction-oxidation, and as previously presented by
Adanez et al. an enhancement on ilmenite reactivity (reaction rate and oxygen transfer capacity) has been reached after first cycles. In this test the oxygen transfer capacity rises by $2 \%$ on the first five cycles whereupon it remains constant.

\section{Acknowledgements}

This research was financially supported by the Picardie Region. The authors are gratefully acknowledged.

\section{REFERENCES}

[1] IPCC, "Contribution of Working Group I to the 4th Assessment Report of the Intergovernmental Panel on Climate Change," In: S. Solomon, et al., Eds., Climate Change 2007: The Physical Science Basis, Cambridge University Press, Cambridge, 2007, p. 996.

[2] I. Dincer, "Environmental Impacts of Energy," Energy Police, Vol. 27, No. 14, 1999, pp. 845-854. doi: 10.1016/j.bbr.2011.03.031

[3] M. Ishida, D. Zheng and T. Akehata, "Evaluation of a Chemical-Looping-Combustion Power-Generation System by Graphic Exergy Analysis," Energy, Vol. 12, No. 2, 1987, pp. 147-154. doi:10.1016/0360-5442(87)90119-8

[4] J. Adanez and L. F. de Diego, "Selection of Oxygen Carriers for Chemical-Looping Combustion," Energy \& Fuels, Vol. 18, No. 3, 2004, pp. 371-377. doi: 10.1021/ef0301452

[5] P. Gayan, L. Dediego, F. Garcialabiano, J. Adanez, A. Abad and C. Dueso, "Effect of Support on Reactivity and Selectivity of Ni-Based Oxygen Carriers for ChemicalLooping Combustion," Fuel, Vol. 87, No. 12, 2008, pp. 2641-2650. doi:10.1016/j.fuel.2008.02.016

[6] K. Sedor, M. Hossain and H. Delasa, "Reactivity and Stability of $\mathrm{Ni} / \mathrm{Al}_{2} \mathrm{O}_{3}$ Oxygen Carrier for Chemical-Looping Combustion (CLC)," Chemical Engineering Science, Vol. 63, No. 11, 2008, pp. 2994-3007. doi:10.1016/j.ces.2008.02.021.

[7] M. Johansson, T. Mattisson and A. Lyngfelt, "Investigation of $\mathrm{Fe}_{2} \mathrm{O}_{3}$ with $\mathrm{MgAl}_{2} \mathrm{O}_{4}$ for Chemical-Looping Combustion," Industrial \& Engineering Chemistry Research, Vol. 43, No. 22, 2004, pp. 6978-6987.

doi: $10.1021 / \mathrm{ie} 049813 \mathrm{c}$

[8] H.-B. Zhao, L.-M. Liu, D. Xu, C.-G. Zheng, G.-J. Liu and L.-L. Jiang, "NiO/ $\mathrm{NiAl}_{2} \mathrm{O}_{4}$ Oxygen Carriers Prepared by Sol-Gel for Chemical-Looping Combustion Fueled by Gas," Fuel, Vol. 36, No. 3, 2008, pp. 261-266. doi:10.1016/S1872-5813(08)60020-1

[9] M. Johansson, T. Mattisson and A. Lyngfelt, "Creating a Synergy Effect by Using Mixed Oxides of Iron- and Nickel Oxides in the Combustion of Methane in a Chemical-Looping Combustion Reactor," Energy, Vol. 56, No. 4, 2006, pp. 2399-2407. doi:10.1021/ef0600681

[10] M. Rydén, A. Lyngfelt, T. Mattisson, D. Chen, A. Holmen and E. Bjørgum, "Novel Oxygen-Carrier Materials for Chemical-Looping Combustion and Chemical-Looping Reforming; $\mathrm{La}_{\mathrm{x}} \mathrm{Sr}_{1-\mathrm{x}} \mathrm{Fe}_{\mathrm{y}} \mathrm{Co}_{1-\mathrm{y}} \mathrm{O}_{3-\delta}$ Perovskites and 
Mixed-Metal Oxides of $\mathrm{NiO}, \mathrm{Fe}_{2} \mathrm{O}_{3}$ and $\mathrm{Mn}_{3} \mathrm{O}_{4}$," International Journal of Greenhouse Gas Control, Vol. 2, No. 1, 2008, pp. 21-36. doi:10.1016/S1750-5836(07)00107-7

[11] E. Jerndal, T. Mattisson and A. Lyngfelt, "Investigation of Different $\mathrm{NiO} / \mathrm{NiAl}_{2} \mathrm{O}_{4}$ Particles as Oxygen Carriers for Chemical-Looping Combustion," Energy, Vol. 94, No. 10, 2009, pp. 665-676. doi:10.1021/ef8006596

[12] A. Abad, J. Adanez, F. Garcialabiano, L. Dediego, P. Gayan and J. Celaya, "Mapping of the Range of Operational Conditions for $\mathrm{Cu}-, \mathrm{Fe}-$, and Ni-Based Oxygen Carriers in Chemical-Looping Combustion," Chemical Engineering Science, Vol. 62, No. 1-2, 2007, pp. 533-549. doi:10.1016/j.ces.2006.09.019

[13] E. Jerndal, T. Mattisson and A. Lyngfelt, "Thermal Analysis of Chemical-Looping Combustion," Chemical Engineering Research and Design, Vol. 84, No. 9, 2006, pp. 795-806. doi:10.1205/cherd05020

[14] H. Leion, A. Lyngfelt, M. Johansson, E. Jerndal and T. Mattisson, "The Use of Ilmenite as an Oxygen Carrier in Chemical-Looping Combustion," Chemical Engineering Research and Design, Vol. 86, No. 9, 2008, pp. 10171026. doi:10.1016/j.cherd.2008.03.019

[15] H. Leion, T. Mattisson and A. Lyngfelt, "Use of Ores and Industrial Products as Oxygen Carriers in ChemicalLooping Combustion," Energy \& Fuels, Vol. 23, No. 4, 2009, pp. 2307-2315. doi:10.1021/ef8008629

[16] J. Adánez, A. Cuadrat, A. Abad, P. Gayán, L. F. de Diego and F. García-Labiano, "Ilmenite Activation during Consecutive Redox Cycles in Chemical-Looping Combustion," Energy \& Fuels, Vol. 24, No. 2, 2010, pp. 14021413. doi: $10.1021 / \mathrm{ef} 900856 \mathrm{~d}$

[17] A. R. Bidwe, F. Mayer, C. Hawthorne, A. Charitos, A. Schuster and G. Scheffknecht, "Use of Ilmenite as an Oxygen Carrier in Chemical Looping Combustion-Batch and Continuous Dual Fluidized Bed Investigation," Energy Procedia, Vol. 4, 2011, pp. 433-440. doi:10.1016/j.egypro.2011.01.072

[18] M. M. Azis, E. Jerndal, H. Leion, T. Mattisson and A. Lyngfelt, "On the Evaluation of Synthetic and Natural Ilmenite Using Syngas as Fuel in Chemical-Looping Combustion (CLC)," Chemical Engineering Research and Design, Vol. 88, No. 11, 2010, pp. 1505-1514. doi:10.1016/j.cherd.2010.03.006

[19] J. Nell, "An Overview of the Phase-Chemistry Involved in Theproduction of High-Titanium Slag from Ilmenite Feedstock," Journal of the South African Institute of Mining and Metallurgy, Vol. 100, No. 1, 2000, pp. 35-44.

[20] R. A. Briggs and A. Sacco, "The Oxidation of Ilmenite and Its Relationship to the $\mathrm{FeO}-\mathrm{Fe}_{2} \mathrm{O}_{3}-\mathrm{TiO}_{2}$ Phase Diagram at 1073 and 1140 K," Vol. 24, No. 6, 1993, pp. 12571264. doi:10.1007/BF02668194

[21] M. Johansson, T. Mattisson and A. Lyngfelt, "Use of $\mathrm{NiO} / \mathrm{NiAl}_{2} \mathrm{O}_{4}$ Particles in a $10 \mathrm{~kW}$ Chemical-Looping Combustor," Industrial \& Engineering Chemistry Research, Vol. 45, No. 17, 2006, pp. 5911-5919. doi:10.1021/ie060232s

[22] P. Kolbitsch, J. Bolhàr-Nordenkampf, T. Pröll and H. Hofbauer, "Operating Experience with Chemical Looping Combustion in a $120 \mathrm{~kW}$ Dual Circulating Fluidized Bed
(DCFB) Unit," International Journal of Greenhouse Gas Control, Vol. 4, No. 2, 2010, pp. 180-185.

doi:10.1016/j.ijggc.2009.09.014

[23] J. Bolhàr-Nordenkampf, T. Pröll, P. Kolbitsch and H. Hofbauer, "Performance of a NiO-Based Oxygen Carrier for Chemical Looping Combustion and Reforming in a 120 kW Unit," Energy Procedia, Vol. 1, No. 1, 2009, pp. 19-25. doi:10.1016/j.egypro.2009.01.005

[24] C. Linderholm, A. Abad, T. Mattisson and A. Lyngfelt, "160 h of Chemical-Looping Combustion in a $10 \mathrm{~kW}$ Reactor System with a NiO-Based Oxygen Carrier," International Journal of Greenhouse Gas Control, Vol. 2, No. 4, 2008, pp. 520-530.

doi:10.1016/j.ijggc.2008.02.006

[25] P. Kolbitsch, T. Proll and H. Hofbauer, "Modeling of a $120 \mathrm{~kW}$ Chemical Looping Combustion Reactor System Using a Ni-Based Oxygen Carrier," Chemical Engineering Science, Vol. 64, No. 1, 2009, pp. 99-108. doi:10.1016/j.ces.2008.09.014

[26] C. Linderholm, T. Mattisson and A. Lyngfelt, "LongTerm Integrity Testing of Spray-Dried Particles in a 10 kW Chemical-Looping Combustor Using Natural Gas as Fuel," Fuel, Vol. 88, No. 11, 2009, pp. 2083-2096. doi:10.1016/j.fuel.2008.12.018

[27] A. Cuadrat, A. Abad, J. Adánez, L. D. Diego, F. GarcíaLabiano and P. Gayán, "Behaviour of Ilmenite as Oxygen Carrier in Chemical-Looping Combustion," Fuel Processing Technologie, Vol. 94, No. 1, 2012, pp. 101-112. doi:10.1016/j.fuproc.2011.10.020

[28] A. Abad, J. Adánez, A. Cuadrat, F. García-Labiano, P. Gayán and L. F. de Diego, "Kinetics of Redox Reactions of Ilmenite for Chemical-Looping Combustion," Chemical Engineering Science, Vol. 66, No. 4, 2011, pp. 689702. doi:10.1016/j.ces.2010.11.010

[29] A. Ould-Dris, Y. Molodtsof and J. F. Large, "A Classification and Design Method for Moving Bed Flow in Pipes," Powder Technology, Vol. 87, No. 1, 1996, pp. 4957. doi:10.1016/0032-5910(96)80758-3

[30] M. L. Vries, I. E. Grey and J. D. Fitz Gerald, "Crystallographic Control in Ilmenite Reduction," Metallurgical and Materials Transactions B, Vol. 38, No. 2, 2007, pp. 267-277. doi:10.1007/s11663-006-9015-0

[31] C. Kucukkaragoz and R. Eric, "Solid State Reduction of a Natural Ilmenite," Minerals Engineering, Vol. 19, No. 3, 2006, pp. 334-337. doi:10.1016/j.mineng.2005.09.015.

[32] P. Pourghahramani and E. Forssberg, "Effects of Mechanical Activation on the Reduction Behavior of Hematite Concentrate," International Journal of Mineral Processing, Vol. 82, No. 2, 2007, pp. 96-105. doi:10.1016/j.minpro.2006.11.003

[33] G. Flamant, D. Gauthier, M. Rivot, A. Rouanet and F. Sibieude, "Mécanismes de Réduction de L'ilménite Naturelle par le Méthane dans un Réacteur à Lit Fluidisé," Powder Technology, Vol. 51, No. 3, 1987, pp. 251-260. doi:10.1016/0032-5910(87)80026-8

[34] C. V. Stevens, "Thermochemical Processing of Biomass: Conversion into Fuels, Chemicals and Power," John Wiley \& Sons, Hoboken, 2011, p. 348.

[35] A. Cuadrat, A. Abad, F. García-Labiano, P. Gayán, L. F. 
de Diego and J. Adánez, "Ilmenite as Oxygen Carrier in a Chemical Looping Combustion System with Coal," Energy Procedia, Vol. 4, 2011, pp. 362-369. doi:10.1016/i.egypro.2011.01.063

[36] A. Cuadrat, A. Abad, F. García-Labiano, P. Gayán, L. F. de Diego and J. Adánez, "The Use of Ilmenite as OxygenCarrier in a $500 \mathrm{~W}_{\text {th }}$ Chemical-Looping Coal Combustion Unit," International Journal of Greenhouse Gas Control, Vol. 5, No. 6, 2011, pp. 1630-1642. doi:10.1016/j.ijggc.2011.09.010

[37] A. Cuadrat, A. Abad, F. García-Labiano, P. Gayán, L. F. de Diego and J. Adánez, "Effect of Operating Conditions in Chemical-Looping Combustion of Coal in a $500 \mathrm{~W}_{\text {th }}$ Unit," International Journal of Greenhouse Gas Control, Vol. 6, 2012, pp. 153-163. doi:10.1016/i.ijggc.2011.10.013

[38] N. Berguerand and A. Lyngfelt, "Design and Operation of a $10 \mathrm{~kW}_{\text {th }}$ Chemical-Looping Combustor for Solid Fuels-Testing with South African Coal," Fuel, Vol. 87, No. 12, 2008, pp. 2713-2726.

[39] N. Berguerand and A. Lyngfelt, "The Use of Petroleum Coke as Fuel in a $10 \mathrm{~kW}_{\text {th }}$ Chemical-Looping Combustor," International Journal of Greenhouse Gas Control, Vol. 2, No. 2, 2008, pp. 169-179. 